\title{
PEMBUATAN TEPUNG UBI UNGU DALAM UPAYA DIVERSIFIKASI PANGAN PADA INDUSTRI RUMAH TANGGA UKM GRIYA KETELAQU DI KELURAHAN PLALANGAN KECAMATAN GUNUNGPATI KOTA SEMARANG
}

\author{
Ali Umar Dhani \\ Fakultas Teknologi Pertanian, Universitas 17 Agustus 1945
}

\begin{abstract}
Abstrak
Tulisan ini bertujuan untuk mengemukakan upaya diversifikasi pangan ubi ungu mulai dari proses produksi tepung ubi ungu dari proses persiapan bahan baku, proses pembuatan tepung ubi ungu, penanganan produk akhir meliputi pengemasan, penyimpanan, analisis usaha dan pemasaran, kondisi sarana dan prasarana yang digunakan. Kegiatan dilaksanakan di Industri Rumah Tangga UKM Griya Ketelaqu di Kelurahan Plalangan Kecamatan Gunungpati Kota Semarang. Metode penelitian yang digunakan adalah deskriptif eksploratif dengan melakukan observasi secara langsung, interview (wawancara) dan studi pustaka yang berkaitan dengan tepung ubi ungu. Hasil penelitian menyimpulkan bahwa UKM Griya Ketelaqu memiliki kemampuan mengolah ubi ungu menjadi produk tepung ubi ungu. Selain olahan tepung ubi ungu UKM Griya Ketelaqu juga mengolah berbagai macam jenis tepung-tepungan seperti tepung umbi-umbian, tepung sayur-sayuran, tepung buah-buahan serta mengolah olahan dari ubi lainnya seperti timus, nugget, peyek tumpi dan singkong keju. Nilai rendemen tepung ubi ungu sebesar $40 \%$. Keuntungan per bulan dari usaha produksi tepung ubi ungu oleh UKM Griya Ketelaqu adalah Rp.605.000,- perbulan. Tepung Ubi Ungu dapat menjadi alternatif diversifikasi pangan karena memiliki kemampuan menghasilkan beberapa produk pangan yang disukai oleh masyarakat
\end{abstract}

Kata Kunci: ubi ungu, diversifikasi, tepung, usaha kecil menengah

\begin{abstract}
This paper aims to highlight the effort of purple sweet potatoes flour diversification beginning from the process of producing sweet potatoes flour from the preparation of raw material, the process of making sweet potatoes flour, the handling of the final product including packaging, storage, business analysis and marketing, the condition of the facilities and infrastructure used. The activity was carried out at the UKM (Small Medium Enterprise) Griya Ketelaqu Home Industry in Plalangan Village, Gunungpati District, Semarang. The method used is descriptive exploratory research by direct observation, interviews with the owner and literature studies relating to purple sweet potato flour. The results of the study concluded that UKM Griya Ketelaqu had the ability to process purple sweet potatoes into purple sweet potato flour products. In addition to processed purple sweet potatoes flour UKM Griya Ketelaqu also processes various types of flour such as tuber flour, vegetable flour, fruit flour as well as processing processed from other sweet potatoes such as timus, nuggets, tofu and cassava cheese. Thus the yield of purple sweet potato flour by 40\%. The profit per month from the purple sweet potato flour production business by Griya Ketelaqu UKM is Rp.605,000 per month. Purple sweet poatoes flour can be an alternative food diversification because it has the ability to produce some food products that are preferred by the community.
\end{abstract}

Keywords: purple sweet potatoes, diversified, flour, small and medium enterprise 


\section{Pendahuluan}

Ubi jalar (Ipomoea batatas L.) atau dalam bahasa Inggrisnya sweet potato adalah sejenis tanaman budidaya. Bagian yang dimanfaatkan adalah akarnya yang membentuk umbi dengan kadar gizi (karbohidrat) yang tinggi. Di Afrika, umbi ubi jalar menjadi salah satu sumber makanan pokok yang penting. Di Asia, selain dimanfaatkan umbinya, daun muda ubi jalar juga dibuat sayuran. Terdapat pula ubi jalar yang dijadikan tanaman hias karena keindahan daunnya. Menurut Kusumayanti dkk. (2016), ubi jalar (Ipomoea batatas L) selain dapat diolah menjadi berbagai macam olahan pangan juga merupakan salah satu sumber devisa negara dan Indonesia merupakan salah satu eksportir utama ubi jalar di pasar internasional. Nilai ekspor ubi jalar pada semester I tahun 2019 mencapai USD 3.851.000,33 (Lidyana, 2019). Tanaman ubi jalar dapat tumbuh di dataran rendah dan dataran tinggi (Rauf \& Lestari, 2009). Salah satu jenis ubi jalar yang banyak ditemui di Indonesia adalah ubi jalar ungu. Ubi jalar ungu (Ipomoea batatas var Ayumurasaki) memiliki kulit dan daging umbi yang berwarna ungu kehitaman. Ubi jalar ungu mengandung pigmen antosianin yang lebih tinggi daripada ubi jalar jenis lain.

Tabel 1

Kandungan Gizi Ubi Jalar dalam Bahan 100 gr Bahan Segar

\begin{tabular}{cc}
\hline Senyawa & Komposisi \\
\hline Energi (kj/100gram) & 71,1 \\
Protein (\%) & 1,43 \\
Lemak (\%) & 0,17 \\
Pati (\%) & 22,4 \\
Gula (\%) & 2,4 \\
Serat Makanan (\%) & 1,6 \\
Kalsium (mg/100gram) & 29 \\
Fosfor (mg/100gram) & 51 \\
Besi (mg/100gram) & 0,49 \\
Vitamin A (mg/100gram) & 0,01 \\
Vitamin B (mg/100gram) & 0,09 \\
Vitamin C (mg/100gram) & 24 \\
Air (gram) & 83,3 \\
\hline
\end{tabular}

Sumber : Syamsir dan Honestin (2009)

Industri rumah tangga yang bernama UKM (Usaha Kecil dan Menengah) Griya Ketelaqu yang terletak di Kecamatan
Gunungpati Kota Semarang mengolah ubi ungu menjadi tepung Ubi Ungu. Ubi ungu diperoleh dari kebun sendiri dan di Pasar 
Bandungan. Kelebihan dari tepung ubi ungu lebih tahan disimpan sehingga penting sebagai penyedia bahan baku industri dan harga lebih stabil dan lebih luwes untuk pengembangan produk pangan dan nilai gizi. Beberapa produk variasi olahan dari singkong dan umbi-umbian yang diproduksi UKM Griya Ketelaqu selain berbagai tepung umbi antara lain timus siap goreng, singkong keju dan nugget. Dalam sekali produksi pengolahan tepung membutuhkan bahan baku kurang lebih 50 kg ubi ungu.

Potensi ubi ungu sebagai salah satu alternatif diversifikasi pangan, dan arti penting usaha kecil dan menengah sebagai ujung tombak pengelolaan produk menjadi alasan penting studi ini. Proses pembuatan tepung ubi ungu UKM Griya Ketelaqu juga tergolong sederhana ditinjau dari segi teknologi pengolahan, peralatan, dan pemasarannya sehingga memerlukan inovasi dalam proses produksi, packing dan pemasarannya. Hasil produksi tepung ubi ungu dijual kepada konsumen yang langsung datang di UKM Griya Ketelaqu yang terletak di Jl. Kyai Sabrang II, Kelurahan Plalangan, Kecamatan Gunungpati, Kota Semarang, Provinsi Jawa Tengah. Penjualan juga dilakukan saat ada bazar di kecamatan, yang diadakan oleh dinas Ketahanan Pangan Kota Semarang ataupun secara online di aplikasi Web. Penelitian yang dilakukan oleh Marta dan Tensiska (2013) dapat membantu masyarakat Desa Sekarwangi dan Desa Cilangkap Kecamatan Buahdua Sumedang dalam peningkatan kemampuan produksi dan pemasaran produk.

\section{Metode Penelitian}

Metode penelitian yang digunakan adalah deskriptif eksploratif dengan melakukan observasi secara langsung dan ikut serta dalam pembuatan tepung ubi ungu di UKM Griya Ketelaqu, melakukan interview (wawancara) dengan pemilik UKM Griya
Ketelaqu, dan studi pustaka dari referensi dengan tepung ubi ungu.

\section{Hasil dan Pembahasan}

Tepung ubi ungu merupakan olahan setengah jadi yang harus diolah kembali untuk menjadi produk makanan. Menurut Ginting dkk. (2014) ubijalar yang kaya akan nilai gizi dan memiliki senyawa bioaktif yang berkhasiat bagi kesehatan, potensial untuk diolah menjadi beragam produk pangan, baik dari umbi segar, pasta maupun tepung dan patinya dengan proporsi penggunaan $10-100$ persen. Upaya ini berkontribusi besar dalam mendukung program diversifikasi pangan karena dapat mengurangi impor terigu, meningkatkan citra dan nilai tambah produk pangan lokal serta meningkatkan pendapatan petani melalui peningkatan produksi ubijalar. Usaha pengolahan ubijalar cukup prospektif ditinjau dari ketersediaan varietas unggul ubijalar untuk penyediaan bahan baku, teknologi pengolahan yang relatif sederhana dan dukungan kebijakan yang mendorong optimalisasi pemanfaatan bahan pangan lokal, sosialisasi/pelatihan, bantuan bibit, modal, dan peralatan serta fasilitas pemasaran. Kendala ketersediaan bahan baku perlu disiasati dengan pengaturan waktu tanam dan panen yang tepat dan pemilihan jenis produk yang dihasilkan.

Tahapan pengolahan tepung ubi ungu dimulai dari pengambilan bahan baku dan sortasi, pengupasan kulit ubi ungu, pencucian ubi ungu, pemotongan ubi ungu menjadi bagian-bagian yang tipis, pengeringan ubi ungu, penggilingan ubi ungu dan pengemasan ubi ungu. Dari setiap tahap proses pengolahan harus benar-benar diperhatikan karena sangat menentukan kualitas produk yang dihasilkan. Adapun penjelasan tahap-tahap pengolahan tepung ubi ungu adalah sebagai berikut : 


\section{a. Pembelian Bahan Baku}

Pembelian bahan baku ubi ungu di Pasar Bandungan, Ambarawa dan juga di lahan pertanian warga dengan cara pembelian sistem tebas. Setelah itu ubi ungu dibawa ke tempat produksi.

\section{b. Sortasi Ubi ungu}

Bahan baku disortasi dengan cara pemilihan ubi ungu dengan kondisi baik tidak terserang hama ulat dan tidak busuk, sedangkan ubi ungu yang tidak sesuai dengan kriteria akan dimanfaatkan menjadi pakan ternak.

\section{c. Pengupasan Ubi Ungu}

Setelah proses sortasi selesai selanjutnya dilakukan tahapan pengupasan kulit ubi ungu, yang dilakukan untuk memisahkan kulit dengan daging ubi ungu. Tujuan pengupasan adalah menghilangkan kulit luar dengan menggunakan pisau. Untuk mengupas kulit ubi ungu sebanyak $50 \mathrm{~kg}$ membutuhkan waktu kurang lebih 2 jam dengan 4 orang yang mengerjakan

\section{d. Pencucian Ubi Ungu}

Ubi ungu yang telah dikupas langsung dimasukkan ke wadah yang berisi air untuk kemudian dicuci. Pencucian diawali dengan menggosok-gosok ubi kayu dengan tangan guna menghilangkan noda tanah yang masih menempel pada ubi ungu saat proses pengupasan. Setelah dicuci diletakkan dikeranjang.

\section{e. Pemotongan Ubi Ungu}

Pemotongan ubi ungu menjadi bagianbagian tipis dengan ketebalan $\pm 1 \mathrm{~cm}$. Pemotongan dilakukan untuk mempercepat proses pengeringan. Kemudian potongan ubi ungu dicuci dengan air bersih untuk menghilangkan getah pada ubi ungu, selanjutnya potongan ubi ungu ditiriskan.

\section{f. Pengeringan Ubi Ungu}

Setelah ubi ungu ditiriskan, selanjutnya ubi ungu ditata rapi pada nampan/baki pengering, dan diletakkan pada rak-rak pengering dalam mesin pengering tray dryer dengan sumber panas Gas LPG atau tumble dryer gas, dikeringkan selama kurang lebih 7 jam pada suhu $70^{\circ} \mathrm{C}$. Menurut Ambarsari dkk. (2009), adalah kadar air maksimal 10\%, kadar abu maksimal 3\%, kadar lemak maksimal $1 \%$, kadar protein minimal 3\%, kadar serat kasar minimal 2\%, dan kadar karbohidrat minimal $85 \%$. Pengelola UKM belum melakukan tes kadar air, kadar abu, kadar lemak, kadar protein, kadar serat kasar, dan kadar karbohidrat sebagaimana rekomendasi dari SNI.

\section{g. Penggilingan Ubi Ungu}

Setelah proses pengeringan, ubi ungu digiling dengan mesin penggiling tepung dengan ukuran sesuai standar SNI, yaitu 80 mesh (Ambarsari dkk., 2009). Rekomendasi SNI untuk tepung ubi jalar menurut Ambarsari dkk. (2009), adalah kadar air maksimal 10\%, kadar abu maksimal 3\%, kadar lemak maksimal 1\%, kadar protein minimal 3\%, kadar serat kasar minimal 2\%, dan kadar karbohidrat minimal $85 \%$. Persyaratan fisik mengikuti persyaratan produk tepung pada umumnya, yaitu bentuk, bau dan warna normal; tidak diperkenankan keberadaan benda-benda asing, dan dengan tingkat kehalusan minimal 95\% produk lolos ayakan 80 mesh.

\section{h. Pengemasan}

Tepung ubi ungu dikemas dalam plastik polietilen ketebalan $0.03 \mathrm{~mm}$ untuk menjaga produk supaya tetap terjaga mutu dan kualitasnya. Menurut penelitian Falihah dkk. (2014) menyimpan mi kering mocaf-ubi ungu yang dikemas menggunakan plastik polietilen (PE) 0,03 $\mathrm{mm}$ mengalami penurunan kualitas seiring waktu penyimpanan, Umur simpan mi kering dari mocaf-ubi ungu yang dikemas menggunakan plastik PE 0,03 $\mathrm{mm}$ mempunyai umur simpan 375 hari (Falihah dkk., 2014). Produk tepung ubi ungu 


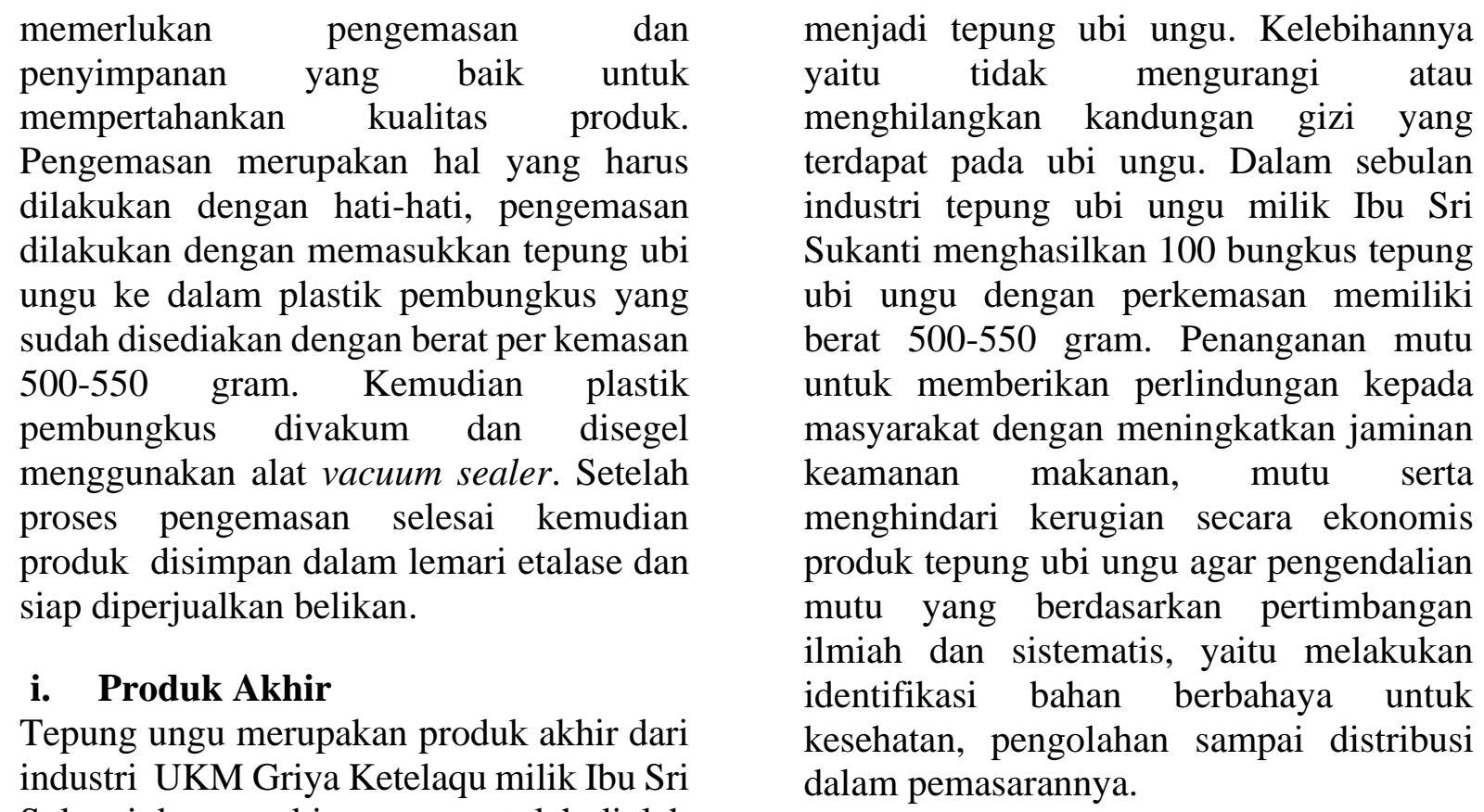

Sukanti, berupa ubi ungu yang telah diolah

Tabel 2

\begin{tabular}{|c|c|c|}
\hline \multicolumn{3}{|c|}{ Ciri-ciri Produk Tepung Ubi Ungu } \\
\hline No & Parameter & Keterangan \\
\hline 1 & Rupa & Serbuk \\
\hline 2 & Warna & Ungu \\
\hline 3 & $\mathrm{Bau}$ & Khas ubi ungu \\
\hline 4 & Tekstur & Halus \\
\hline 5 & Rasa & Ubi ungu \\
\hline
\end{tabular}



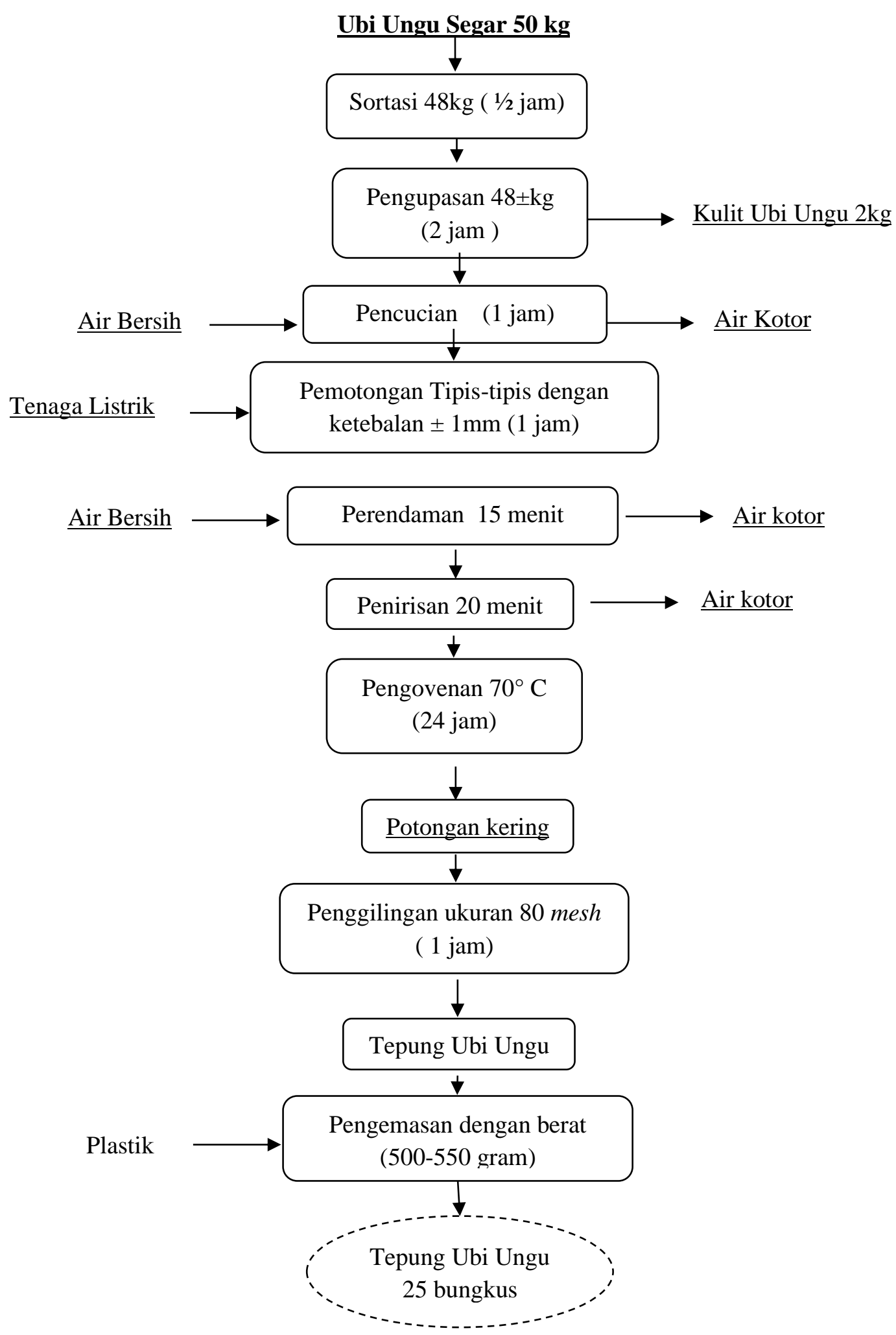

Gambar 2.

Diagram Alir Kuantitatif Proses Pengolahan Tepung Ubi Ungu 


\section{Analisis Biaya Produksi}

\section{Biaya Produksi}

Biaya produksi adalah semua pengeluaran ekonomis yang harus dikeluarkan untuk memproduksi suatu barang. Biaya produksi di UKM Griya Ketelaqu bahan baku dan biaya yang dikeluarkan untuk mendapatkan faktor-faktor penunjang produksi yang akan di gunakan untuk menghasilkan suatu produk. Bahan dasar dalam pembuatan tepung ubi ungu adalah ubi ungu segar. Dalam setiap produksi UKM Griya
Ketelaqu membutuhkan rata-rata $50 \mathrm{~kg}$ ubi ungu dan menghasilkan tepung ubi ungu 20 kg. Dengan demikian nilai rendemen tepung ubi ungu sebesar $40 \%$.

\section{Biaya Bahan Baku dan Bahan Penunjang}

Proses produksi biasanya diselesaikan dalam waktu satu hari dan hanya untuk satu kali pengolahan tepung ubi ungu. Biaya yang dikeluarkan untuk setiap proses produksi tepung ubi ungu di UKM Griya Ketelaqu sebagai berikut :

Tabel 3.

Bahan Baku dan Penunjang Dalam Satu Kali Proses Produksi

\begin{tabular}{llcc}
\hline Bahan & Kebutuhan & $\begin{array}{c}\text { Harga Satuan } \\
(\mathbf{R p})\end{array}$ & Jumlah (Rp) \\
\hline Ubi Ungu & $50 \mathrm{Kg}$ & 2.500 & 125.000 \\
Plastik & 1 roll & 2.500 & 2.500 \\
Stiker & 20 stiker & 5.000 & 10.000 \\
BBM & 2 Liter & 9.000 & 18.000 \\
Gas Tabung & 1 & 22.000 & 22.000 \\
\hline Jumlah & & & $\mathbf{1 7 7 . 5 0 0}$ \\
\hline
\end{tabular}

Sumber : UKM Griya Ketelaqu

Griya Ketelaqu dalam satu bulan melakukan 2 kali pengolahan tepung ubi ungu sehingga dalam 1 bulan membutuhkan biaya: kebutuhan biaya proses produksi $=\mathrm{Rp} 177.500 \times(2 \mathrm{kali}$ produksi $)=\mathbf{R p . 3 5 5 . 0 0 0 , - . ~ N a m u n ~ b i a y a ~}$ ini belum termasuk biaya listrik dan air. Sedangkan untuk biaya tenaga kerja Rp.300.000 karena proses pembuatan tepung ubi ungu ini dilakukan oleh pemilik usaha.

\section{Biaya Listrik dan Air PDAM}

Disebabkan tempat usaha produksi tepung ubi ungu sekaligus tempat tinggal maka untuk pemakaian listrik dan air berdasarkan pengeluaran biaya listrik PLN dan air
PDAM perbulan, yaitu listrik PLN sebesar Rp50.000,-sedangkan biaya air PDAM sebesar Rp. 10.000,-. Total biaya produksi perbulan UKM Griya Ketelaqu adalah = Biaya bahan baku + biaya penunjang + biaya listrik + biaya air PDAM + biaya tenaga kerja $=355.000+50.000+10.000+$ $300.000=$ Rp.715.000,-

\section{Hasil Penjualan}

UKM Griya Ketelaqu menjual tepung ubi ungu dengan harga per bungkusnya. Rp.22.000,-. Dalam satu hari tepung ubi rata-rata terjual 2 bungkus. Apabila di ratarata pendapatan perbulannya adalah $\mathrm{Rp}$ 44.000 x 30 hari sebesar Rp 1.320.000,- 


\begin{tabular}{|c|c|c|c|}
\hline Bahan & Satuan & Harga & Jumlah \\
\hline Gula & $10 \mathrm{~kg}$ & Rp 11.000 & Rp 110.000 \\
\hline Jahe & $5 \mathrm{~kg}$ & $\mathrm{Rp} 12.000$ & $\operatorname{Rp} 60.000$ \\
\hline Rempah & & $\operatorname{Rp} 6.000$ & $\operatorname{Rp} 6.000$ \\
\hline Label & 400 biji & Rp 50 & Rp 20.000 \\
\hline Gas & Setiap produksi & $\operatorname{Rp} 7.500$ & $\mathrm{Rp} 7.500$ \\
\hline Plastik Besar & & $\operatorname{Rp} 7.500$ & $\mathrm{Rp} 7.500$ \\
\hline Plastik Kecil & & $\operatorname{Rp} 6.000$ & $\operatorname{Rp} 7.500$ \\
\hline Tenaga Produksi & & $\operatorname{Rp} 15.000$ & Rp 15.000 \\
\hline Tenaga Packing & & $\operatorname{Rp} 20.000$ & Rp 20.000 \\
\hline Jumlah Total & & & Rp 253.000 \\
\hline
\end{tabular}

\section{Keuntungan}

Keuntungan yang diperoleh Industri UKM Griya Ketelaqu dalam satu bulan adalah : Total keuntungan $=$ Jumlah hasil penjualan produk dikurangi dengan biaya produksi, Jadi total keutungan UKM Griya Ketelaqu dalam satu bulan adalah :

$=$ Rp. $1.320 .000-\mathrm{Rp} \cdot 715.000=\mathrm{Rp}$. 605.000,- perbulan.

\section{Kesimpulan}

UKM Griya Ketelaqu adalah industri rumah tangga yang mengolah ubi ungu menjadi produk tepung ubi ungu. Selain olahan tepung ubi ungu UKM Griya Ketelaqu juga mengolah berbagai macam jenis tepung-tepungan seperti tepung umbiumbian, tepung sayur-sayuran, tepung buah-buahan serta mengolah olahan dari

\section{Daftar Pustaka}

Ambarsari, I., Sarjana, S., \& Choliq, A. 2009. Rekomendasi dalam penetapan standar mutu tepung ubi jalar. Jurnal standardisasi, 11(3), 212-219.

Falihah, A., Sutardi, S., \& Supriyadi, S. (2014). Pengaruh Jenis dan Tebal Plastik Pengemas terhadap Umur Simpan Mi Kering dari Mocaf-Ubi Ungu: Studi Kasus di UKM Putri 21, Playen, Gunung Kidul ubi lainnya seperti timus, nugget, peyek tumpi dan singkong keju.

Bahan dasar dalam pembuatan tepung ubi ungu adalah ubi ungu segar. Dalam setiap produksi UKM Griya Ketelaqu membutuhkan rata-rata $50 \mathrm{~kg}$ ubi ungu dan menghasilkan tepung ubi ungu $20 \mathrm{~kg}$. Dengan demikian nilai rendemen tepung ubi ungu sebesar $40 \%$. Keuntungan per bulan dari usaha produksi tepung ubi ungu oleh UKM Griya Ketelaqu adalah Rp. 605.000,- perbulan.,- (Sembilan ratus lima ribu rupiah).

Ubi ungu dapat menjadi alternatif diversifikasi pangan sehingga perlu dikelola dengan baik dan masih memerlukan upaya promosi dan pengembangan pemasaran.

Universitas Gajahmada, Yogyakarta. Retrieved from http://etd.repository.ugm.ac.id/hom e/detail_pencarian/76991

Ginting, E., Yulifianti, R., \& Jusuf, M. J. M. 2014. Ubijalar Sebagai Bahan Diversifikasi Pangan Lokal Sweet Potatoes as Ingredients of Local Food Diversification. Jurnal Pangan, 23(2), 194-207.

Kusumayanti, H., Ahmad, L. F., Setiawati, F. N., \& Ginting, S. B. 2016. Pengolahan Ubi Jalar (Ipomoea 
batatas L) Dengan Sistem Kering Untuk Meningkatkan Komoditas Pangan Lokal. METANA, 12(2), 39-44.

Lidyana, V. (2019). RI Ekspor 15 Ribu Ton Tanaman Pangan, Paling Banyak Ubi, DetikFinance. Retrieved from https://finance.detik.com/beritaekonomi-bisnis/d-4663001/riekspor-15-ribu-ton-tanamanpangan-paling-banyak-ubi

Marta, H., \& Tensiska. 2013. Pembuatan Berbagai Produk Ubi Jalar Dalam Upaya Diversifikasi Pangan dan Peningkatan Gizi Masyarakat di Desa Sekarwangi dan Desa Cilangkap Kecamatan Buahdua Kabuapaten Sumendang.
Dharmakarya: Jurnal Aplikasi Ipteks untuk Masyarakat, 2(2), 8592.

Rauf, A. W., \& Lestari, M. S. 2009. Pemanfaatan komoditas pangan lokal sebagai sumber pangan alternatif di Papua. Jurnal Litbang Pertanian, 28(2), 54-62.

Syamsir, E., \& Honestin, T. 2009. Karakteristik Fisiko-Kimia Tepung Ubi Jalar (Ipomoea Batatas) Varietas Sukuh Dengan Variasi Proses Penepungan [PhysicoChemical Characteristics of Sukuh Variety Sweet Potatoes (Ipomea batatas) Flours Made with Various Methods]. Jurnal Teknologi dan Industri Pangan, 20(2), 90. 